\title{
Da história da dramaturgia às séries da
} televisão

From the history of dramaturgy to the television series

\section{Tania Cristiane Fukushima}

Mestranda em Comunicação e Inovação na Universidade Municipal de São Caetano do Sul - USCS; professora universitária para cursos de graduação e pós-graduação; consultora de Planejamento Estratégico de Marketing e Vendas.

O livro de Nesteriuk é a primeira obra em língua portuguesa publicada no Brasil sobre o processo de criação da narrativa dos desenhos animados, licenciada pelo Creative Commons.

Seu conteúdo faz uma bela retrospectiva da história das séries de televisão, a partir das primeiras produções, evidenciando os contextos da evolução e as narrativas de animação tecnológicas. Pela experiência do autor no projeto AnimaTV ${ }^{2}$, o livro também possui a riqueza de informações do Projeto Complementa, com os conceitos técnicos da área de produção e detalhes sobre os bastidores dos processos criativos, de desenvolvimento e de produção das séries, detalhando a complexidade das construções das animações e orientando os profissionais da área para novas produções.

Em um contexto de 283 páginas, Sérgio Nesteriuk descreveu, a princípio, as primeiras narrativas na TV, traçando as experiências adaptadas para o Brasil e os conceitos técnicos da produção, finalizando com o estudo de alguns casos-piloto de qualidade que, inclusive, estão à disposição para ser assistidos através dos links citados pelo autor.

O livro, muito bem-humorado através de ilustrações dos momentos e estados críticos vividos pelo produtor (em imagens do seu comportamento), apresenta, de forma lúdica, as cognições diante dos processos de produção.

Nos primeiros capítulos, que o autor chamou de "Formas predecessoras da narrativa", ele contextualizou os princípios da comunicação e a produção em massa das publicações na Revolução Industrial, sempre conciliando o momento de vivência da comunicação no Brasil com as produções artísticas de cada época.
Partindo-se da introdução à produção impressa até os modelos de animações do cinema e incluindo-se, em detalhes, os recursos e as ferramentas disponíveis para cada período, são citados diversos personagens que marcaram época, como Gato Felix, entre os anos de 1919

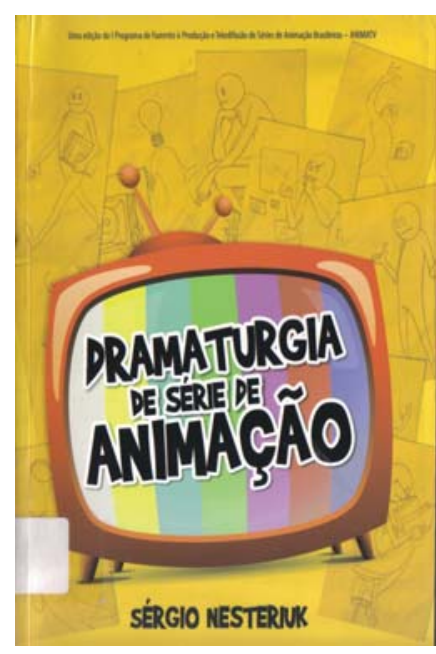
e 1936; Mickey, em 1928; e Zé Carioca, em 1944 - todos criados por Walt Disney em viagem pelo Brasil.

Nos anos 1960, marcados pelo fim do período conhecido como animação clássica, esta deu espaço a uma nova animação com filmes de longa-metragem, como "A pantera cor-de-rosa", em 1963, até "A era do gelo", em 2002.

Por outro lado, o livro em referência aborda também todas as mudanças e adaptações dos grandes produtores americanos e a trajetória completa que a dramaturgia sofreu com as adaptações aos interesses sociais e econômicos. Vale destacar, ainda, o marco das entradas dos anunciantes, as restrições das propagandas ao público infantil e as exigências educativas e sociais. Assim, observa-se a menção a diversas séries, pressionadas pelo interesse comercial, que foram baseadas em brinquedos criados a partir do licenciamento conhecido como toys-cum-cartoons, como "He-Man" (1983), "Transformers" (1984), "Thundercats", em 1985, e "Os caça-fantasmas", em 1986.

A partir do início das produções de séries de animação na televisão brasileira pela TV Tupi, cita-se como referência histórica o "Pica-Pau", em 1950, e, a partir da primeira metade da década de 1960, são mencionadas as séries

\footnotetext{
${ }^{1}$ Nesteriuk, Sérgio. Dramaturgia de série de animação. São Paulo: Sergio Nesteriuk, 2011. 283p.

2 Primeiro Programa de Fomento à Produção e Teledifusão de Séries de Animação Brasileiras.
} 
dubladas exibidas pela Rede Globo, como "Jambo e Ruivão", em 1965, "Shazzan”, em 1967, e a primeira série desenvolvida no Brasil, " A turma da Mônica”, em 1981.

Já no capítulo seguinte, o autor descreveu conceitos técnicos quanto à produção das séries, desde o conceito de conteúdo, cenários e personagens, até a sinopse comercial e a complexidade na construção da dramaturgia, assim como a adaptação das novas tecnologias disponíveis para a produção das séries.

[...] O terceiro capítulo parte do aproveitamento das reflexões e das ideias apresentadas nos capítulos anteriores para apresentar os itens constituintes de uma bíblia de produção, amplamente utilizada no mercado internacional de projetos de séries de animação (NEsteriuK, 2011: 151).

O quarto capítulo, por sua vez caracteriza-se pelo conteúdo com estudo de casos de diversas séries, cuidadosamente selecionadas pelo autor.

Em suas considerações finais, Nesteriuk apresentou aos profissionais da área e aos futuros animadores e produtores de projetos de animação uma relação com 15 dicas importantes para ajudá-los no sucesso de seus empreendimentos.

Para o leitor, o histórico das narrativas produz uma viagem ao "túnel do tempo" das principais séries vivenciadas como telespectador, conduzindo-o ao conhecimento dos bastidores e à frustração dos interesses políticos e econômicos que desmancham toda a ilusão sobre os personagens $\mathrm{e}$ as narrativas vividas em épocas distintas. A linha do tempo e a evolução da dramaturgia se confundem bastante com os grandes teóricos da comunicação, e podem ser bem observadas as trajetórias das narrativas na TV brasileira e nos países que desenvolveram seu estilo de criação, como o Japão e os Estados Unidos.

Alguns personagens e séries são somente descritos como marco da evolução das propostas das séries enquanto outros são altamente criticados pelo autor, o que traz a dúvida se suas considerações foram elaboradas sob o aspecto técnico da produção ou se externaram suas opiniões pessoais sobre o tema e/ou uma identificação com os personagens das séries.

A proposta de Nesteriuk é excelente quanto à apresentação dos conceitos e à formação de uma bíblia de produção; no entanto, é percebido o desenvolvimento de dois temas em um só livro, um para o leitor buscando o histórico das séries de TV e outro para o produtor de animações em busca de conhecimento técnico de produção.

A recomendação da leitura fica dividida entre os amantes das séries narrativas da televisão e os profissionais da área técnica que buscam atualização das novas ideias e evolução dos processos de produção e análise crítica de casos. Para os estudantes de Comunicação Social, principalmente aqueles que pretendem seguir a carreira das produções técnicas, o conteúdo é bastante didático e as produções de imagens foram bem elaboradas pelo autor, identificando com clareza os momentos vividos pelo produtor em sua carreira, entre a crítica, a dúvida, a aceitação e o sucesso.

\section{0 autor do livro}

Sérgio Nesteriuk é graduado em Comunicação Social Rádio e Televisão, pela Universidade Estadual Paulista Unesp, possuindo mestrado e doutorado em Comunicação e Semiótica, pela Pontifícia Universidade Católica de São Paulo - PUC/SP. Leciona disciplinas relacionadas a projetos, roteiro, animação, games e hipermídia, além de orientar projetos de naturezas diversas nos cursos de Animação, Design de Games, Comunicação em Multimeios e Tecnologia e Mídias Digitais. Além disso, atua como realizador independente nas áreas de audiovisual, produção sonora e hipermídia, e como consultor de roteiros e projetos, tendo já atuado como consultor de roteiro e dramaturgia para o AnimaTV.

Possui diversas produções artísticas, como "Videoridade" (1999), "Eu(s)?" (1999), "Mentes (de)mentes" (1998).

O livro encontra-se disponível para leitura através do link: http://3dvicio.blogspot.com/2011/04/livro-dramaturgia-deserie-de-animacao.html 